\title{
류마티스관절염의 생물학적제제치료
}

최 성 재

고려대학교 의과대학 류마티스내과

\section{Biologic therapies for the treatment of rheumatoid arthritis}

\section{Sung-Jae Choi, MD}

Department of Rheumatology, Korea University College of Medicine, Seoul, Korea

Rheumatoid arthritis (RA) is a chronic autoimmune disease that primarily affects the synovial joints. If left untreated, persistent synovial inflammation can lead to cartilage and bone destruction, ultimately causing significant longterm disability and mortality. However, since the late 1990s, the combined use of methotrexate, a synthetic diseasemodifying antirheumatic drug (DMARD), and a biological DMARD has revolutionized the treatment of RA. As of 2021, the Korea Food and Drug Administration has approved seven biological DMARDs for RA treatment: four tumor necrosis factor-alpha inhibitors (infliximab, etanercept, adalimumab, and golimumab) and three non-tumor necrosis factor biological products (abatacept, rituximab, and tocilizumab). Although the use of biological products has allowed significant advances in the treatment of RA, there are certain drawbacks, such as high cost, increased infection risk, and the necessity for parenteral route product administration. Therefore, discontinuation of biological DMARD use without a resulting disease flare is the next treatment goal and a desirable result from the standpoint of risk reduction and cost-effectiveness, especially for patients with clinical remission. It is still unclear which biological product is the best. Clinicians must, therefore, personalize the sequence and strategy of treatment by considering patient characteristics, disease activity, comorbidity, and economic condition

Key Words: Rheumatoid arthritis; Treatment; Biological products; Antirheumatic drugs

\section{서론}

류마티스관절염(rheumatoid arthritis)은 만성 면역매개 염증성질환으로, 활막의 지속적인 염증과 관절 파괴의 진행

Received: January 8, 2021 Accepted: January 18, 2021

Corresponding author: Sung-Jae Choi

E-mail: csjmd888@korea.ac.kr

(C) Korean Medical Association

This is an Open Access article distributed under the terms of the Creative Commons Attribution Non-Commercial License (http://creativecommons. org/licenses/by-nc/3.0) which permits unrestricted non-commercial use, distribution, and reproduction in any medium, provided the original work is properly cited.
이 특징이다. 질병이 진행하면 장애가 유발되고 삶의 질이 낮아진다. 류마티스관절염은 한국에서 $0.3 \%$ 정도의 유병률 을 보이고 있으며, 남성보다 여성의 유병률이 높다[1]. 류마 티스관절염의 치료목표는 활막의 염증을 억제하고, 통증을 줄이며, 관절 파괴를 막아서 신체기능의 악화를 예방하는 것 이다. 종양괴사인자(tumor necrosis factor, TNF)나 인터루 킨(interleukin, $\mathrm{IL})-6$ 등의 전염증성 사이토카인들이 류마 티스관절염 병태생리에 중요하다. 생물학적제제는 분자량이 큰 단백질이며 세포막을 투과하는 능력이 없다[2]. 따라서, 생물학적제제는 세포 밖의 염증 매개물질을 높은 특이도로 겨냥한다. 이런 생물학적제제에는 전염증성 사이토카인들과 
세포막 관련 면역단백들이 있다[3]. 1990년대 말부터 20여 년간 사용된 항TNF 제제 등의 생물학적제제는 류마티스관 절염 치료에 큰 진보를 가져왔다. 하지만, 단백유도 생물학 적제제는 감염증 발생위험이 높고, 주사 형태이며 가격이 비 싼 단점이 있다. 최근 류마티스관절염 환자의 적절한 약물치 료 전략에 대해 본지에 소개된 글에서, 고전적 항류마티스제 와 생물학적제제, 소분자 억제제에 대한 좋은 소개가 있었다 [4]. 따라서 이 글에서는 류마티스관절염 치료제 중 주로 생 물학적제제의 종류와 기전, 장단점을 살펴보고, 생물학적제 제의 사용전략과 류마티스관절염 질병의 관해 도달 시 생물 학적제제의 감량과 중단에 대해 알아보고자 한다

\section{항TNF 제제}

항TNF 제제들은 류마티스 생물학적 치료제들 중에 가장 처음 소개된 약물이다. 아달리무맙은 인간단클론 항체로 매 2 주마다 $40 \mathrm{mg}$ 을 피하주사한다. 에타너셉트는 TNF 수용 체 융합 단백으로 매주 $50 \mathrm{mg}$ 을 피하주사한다. 인플릭시 맙은 키메라 단클론 항체로 로딩 후에 8주마다 $3 \mathrm{mg} / \mathrm{kg}$ 로 정맥주사한다. 골리무맙은 인간단클론 항체로 4 주마다 $50 \mathrm{mg}$ 피하주사하거나 8주마다 $2 \mathrm{mg} / \mathrm{kg}$ 로 정맥주사한다. 서톨리주맙 페골은 $\mathrm{TNF}$ 에 대한 $\mathrm{PEG}$ 화 항원결합 조각으로 인간단클론 항체이며 2주내지 4 주마다 한 번씩 피하주사한 다. 항류마티스제 선택은 환자의 동반질환이나 치료에 대한 금기여부에 따라 결정한다. 인플릭시맙 $10 \mathrm{mg} / \mathrm{kg}$ 용량 투 여 시 심부전이 새로 발생하거나 기존 심부전의 악화가 보 고되었으므로[5], 항TNF 제제는 심부전 환자들에게서 사용 할 수 없다. 하지만, 항TNF 제제를 투여 받는다고 모든 환 자에서 심부전이 새로 발생하는 것은 아니어서, 국내 허가 는 NYHA (New York Heart Association) class 3/4의 중 등도 이상 심부전에서는 금기이다. 항TNF 제제들은 약제 별로 허가사항이 조금 다른데, 특히 인플릭시맙과 골리무 맙은 류마티스관절염 치료 시에는 반드시 메토트렉세이트 (methotrexate, MTX)와 병용하여야 한다. 생물학적제제 는 심각한 감염의 위험도가 증가하여 고식적 질병조절 항
류마티스 약물(conventional synthetic disease modifying anti-rheumatic drug, csDMARDs)보다 1,000인년당 6명 정도의 추가 감염이 발생하는 것으로 보고되었다 [6,7]. 특 히 TNF 억제는 결핵의 위험도가 증가하는 것으로 알려져, 잠복결핵의 스크리닝과 치료가 항 TNF 제제 치료 시작 전에 필수적이다[8].

\section{IL-6 억제제}

IL-6는 T세포, B세포, 대식세포, 파골세포 등을 활성화 시키며, 급성기 반응에도 중요하다. 토실리주맙은 인간 항 IL-6 수용체 단클론항체이며, 류마티스관절염의 치료로 승 인되었다. 토실리주맙은 정맥주사 혹은 피하주사 모두 가능 하다. 정맥주사나 피하주사 모두 효과와 안전성이 비슷한데, 다만 피하주사에서 주사 부위 반응이 좀더 흔하다[9]. 토실 리주맙은 $\operatorname{csDMARDs}$ 나 다른 생물학적제제에 비해 하부 위 장관 천공의 위험이 높다[10]. 따라서 이전에 게실염 병력 이 있는 사람은 토실리주맙이 금기이다. 토실리주맙과 사릴 루맙은 IL-6 수용체를 차단하는 항체이며, 다른 IL-6 사이 토카인을 직접 겨냥한 약제들이(시루쿠맙, 올로키주맙, 클 라자키주맙) 추가적으로 연구 중이다[11,12]. 사릴루맙은 류 마티스관절염 치료로 미국 식품의약국(US Food and Drug Administration, $\mathrm{FDA}$ ) 승인을 받았으나 아직 국내 허가되 지 않았다. $\mathrm{IL}-6$ 억제제들은 특히 부작용이나 금기 때문에 MTX를 쓸 수 없는 환자에서 단독치료로 유용하다. Actemra Versus Methotrexate Double-blind Investigative Trial in Monotherapy (AMBITION) 연구에서 토실리주맙 단 독치료는 MTX 단독치료에 비해 효과가 우수함이 입증되 었다[13]. Actemra Versus Methotrexate Double-blind Investigative Trial in Monotherapy (AMBITION) 연구는 MTX 치료를 지속하기 곤란한 류마티스관절염 환자들을 대 상으로 아달리무맙 혹은 토실리주맙을 단독투여하는 연구 인데, 토실리주맙이 질병활성도(Disease Activity Score 28, DAS28) 조절이 우세한 것으로 나타났다[14]. 사릴루맙 역 시 아달리무맙과 단독 요법으로 직접비교 연구를 하였는 
데, DAS28 조절 측면에서 우세한 것으로 나타났다. 이런 연구들을 바탕으로 유럽류마티스학회(European League Against Rheumatism, EULAR)에서 csDMARDs 병합치료 가 곤란한 경우에, $\mathrm{IL}-6$ 억제제가 다른 생물학적제제보다 장점이 있다고 권고하였다[15].

\section{$\mathrm{CD} 80 / 86$ 억제제}

아바타셉트는 인간 면역글로불린 $\operatorname{IgG1}$ 의 Fc부위와 세포 독성 $\mathrm{T}$ 림프구 항원의 세포 외 부위를 융합하여 만든 융합 단백이다. 세포독성 $\mathrm{T}$ 림프구 항원은 항원제시 세포와 $\mathrm{T}$ 세 포 사이의 신호가 충분히 진행되었을 경우, "자연차단 스위 치(natural off switch)" 개념으로 공동자극을 차단한다. 항 $\mathrm{TNF}$ 제제 치료에 불충분한 반응을 보인 류마티스관절염 환자들에서 아바타셉트 치료는 임상증상뿐만 아니라 기능 적인 효과도 입증했다[16]. 아바타셉트는 항원제시 세포의 $\mathrm{CD} 80 / 86$ 분자(B7-1, B7-2라고도 알려져 있다)에 결합하 는데 T세포의 $\mathrm{CD} 28$ 와의 결합을 방지하여 $\mathrm{T}$ 세포의 활성화 를 억제한다. 다른 기전으로는 아바타셉트의 기전 중에 대식 세포의 이동을 간섭하여 류마티스관절염에 효과를 보일 것 이라는 의견도 있다. 아바타셉트는 생물학적제제들 중에서 중증 감염률이 가장 적고 시간이 지나도 더 증가하지 않는 다. 아바타셉트 피하주사제는 아달리무맙에 비해 부작용으 로 투여를 중단해야 하는 경우가 더 적었고, 주사부위 부작 용도 적었다. 아바타셉트는 인플리시맙에 비해 중증 부작용, 주입 반응, 감염이 더 적게 생겼고 폐암이나 악성종양 발생 증가와 관련이 없었다[17].

\section{$\mathrm{CD} 20$ 억제제}

리툭시맙은 유전자 조작으로 합성된 키메라 단클론 항체 로서 $\mathrm{CD} 20$ 양성 $\mathrm{B}$ 세포를 표적으로 한다. $\mathrm{B}$ 세포 결핍 상태 가 지속되면 자가항체 생성도 감소하게 되고, 이어서 $\mathrm{T}$ 세포 로의 항원 제시도 억제되는 것으로 생각된다[18]. 24주간 리
툭시맙을 MTX와 병합하여 1 사이클 투여하면, 한 가지 혹 은 그 이상의 항 TNF 제제에 불충분한 반응을 보이는 활성 류마티스관절염 환자에서 의미 있는 질병활성도의 호전을 보인다[19]. 리툭시맙은 다발성경화증이나 림프증식질환 등 의 동반질환이 있을 때 생물학적제제 중 첫 번째 선택이 될 수 있다. 하지만, B형간염 보균자에서 B형간염 바이러스 재 활성화 위험이 가장 큰 편이므로, 위험군에서는 피하는 것이 좋다[20]. 다른 생물학적제제와 달리, 리툭시맙에서 특이적 으로 보이는 드문 합병증으로 진행성 다초점성 백질뇌병증 이 발생한 보고가 있다[21]. 오크렐리주맙은 인간 항-CD20 항체로 $\mathrm{FDA}$ 승인을 받은 다발성경화증 치료제이다. 오크 렐리주맙은 리툭시맙보다 B세포 결핍을 더 오래 유도한다. 오크렐리주맙도 류마티스관절염에서 효과를 보였으나 아직 $\mathrm{FDA}$ 승인을 받지 못하였다[22]. 오파투무맙도 CD20 분자를 겨냥한 항체인데 무작위임상연구에서 MTX 불응성 환자에 서 24주째에 임상적 효과를 보였다[23].

\section{다른 생물학적제제들}

류마티스관절염 치료의 표적 중 새로 주목되는 기전 으로 과립구-대식세포 집락-자극인자(granulocytemacrophage colony-stimulating factor, GM-CSF) 경로가 있다. GM-CSF는 전염증성 사이토카인으로, 대식세포, 수 지상세포, 호중구 등의 생존과 분화, 활성에 관여한다[24]. $\mathrm{GM}-\mathrm{CSF}$ 사이토카인과 그 수용체는 류마티스관절염 환자 의 활막 조직이나 단핵구에서 과발현 된다. GSK3196165 는 GM-CS에 대한 인간 단클론 항체로, 2상 임상연구에서 DAS28 점수나 EULAR 반응률에서 개선을 보였다[25].

류마티스관절염 병인에서 $\mathbb{L}-1$ 이 중요한 역할을 하는 것 으로 알려졌으나, $\mathbb{L}-1$ 길항제인 아나킨라는 다른 생물학적 제제보다 류마티스관절염 치료에서 성적이 상대적으로 덜 효 과적이며, 부작용은 항 TNF 제제보다 높았다[26]. 하지만 아 나킨라의 경우, 주기적인 발열, 중성구 증가, 관절통, 근육 통을 주증상으로 하는 몇몇 자가염증질환들과 성인형스틸병, 통풍에서 효과가 뛰어나다. 
IL-12/23 억제제인 유스테키누맙과 $\mathbb{L}-23$ 억제제인 구 셀쿠맙은, 건선 치료에 좋은 반응을 보이고 있으나 MTX불 응성 류마티스관절염 환자의 질병활성도를 유의하게 조절하 는 데는 실패하였다[27]. IL-17 또한 류마티스관절염 환자들 관절과 혈액에서 높게 나타나고, $\mathrm{L}-17$ 의 종류 중에서 특히 IL-17A가 류마티스관절염의 발생기전 중 하나로 생각된다 [28]. 하지만, IL-17A 길항제인 세쿠키누맙과 브로달루맙은 류마티스관절염 치료에서 효과가 낮게 나타났다[29,30]. 익 세키주맙 또한 $\mathbb{L}-17 \mathrm{~A}$ 에 대한 고친화력 단클론항체인데, 생 물학적제제 사용력이 없는 환자나 항TNF 제제 반응부족 환 자에서 류마티스관절염 증상과 징후를 개선시켰다[31]. 하지 만, 전반적으로 $\mathbb{L}-17 \mathrm{~A}$ 경로를 표적으로 하는 치료는 $\mathrm{TNF}$ 나 IL-6 같은 염증성 사이토카인을 차단하는 치료에 비해 효 과가 덜하다(Figure 1) [32].

\section{류마티스관절염 치료에서 생물학적제제에 대한 권고: 어떤 생물학적제제가 더 우수한가?}

EULAR에서는 류마티스관절염 진단과 함께 부작용이나 금기가 없다면 MTX같은 $\mathrm{csDMARDs}$ 로 치료를 시작하라고 권고한다[15]. 하지만, MTX 단독치료만으로는 많은 수의 환 자가 관해 혹은 낮은 질병활성도에 도달할 수가 없다[33]. 나 쁜 예후인자(항-CCP항체가 높거나, 질병활성도가 높고, 기 능적 장애가 있을 때, 골 미란이 있을 때)가 있거나 두 가지 이상의 $\operatorname{csDMARDs}$ 치료에 반응이 부족할 경우, 다음 단계 로 생물학적제제나 표적합성 항류마티스제를 고려해야 한 다. 국내 실정은 나쁜 예후인자가 있더라도, 두 가지 이상 의 $\mathrm{csDMARDs}$ 를 각 3 개월 이상, 총 6 개월 이상 사용하여 효 과가 불충분한 경우만을 급여 인정하고 있다. 생물학적제제 는 MTX와 대부분 병용치료하고 있으나, 약 $1 / 3$ 의 환자에 서 MTX 복용이 불가한 경우가 있어서 대략 $30 \%$ 의 환자는 생물학적제제 단독치료를 받고 있다[34]. 현재 사용 가능한 생물학적제제들 간에 어떤 것이 먼저 사용되어야 하고, 우 세한지는 정해진 바가 없어, 직접비교연구가 필요하다. 아
직 근거 기반으로 하기에는 생물학적제제 사이의 직접비교 연구가 적으므로, 환자들에게 최선의 치료를 선택하는 데에 는 레지스트리연구 결과나 비용-효과적인 면도 고려해야 한 다[35,36].

표적치료전략은 관절 손상을 예방하고, 삶의 질을 최적화 하기 위한 류마티스관절염 치료전략이다[37]. 관해가 치료 의 목표이고, 임상증상의 엄격한 조절과 신속한 치료제의 조절이 표적치료전략의 방법으로, 최소 1-3개월에 한번은 질병활성도를 평가하고 표적에 도달하지 못하였을 경우 다 른 치료방법으로 교체한다. 이런 표적치료전략은 American College of Rheumatology (ACR), EULAR, 아시아태평양 류마티스학회(Asia Pacific League of Associations for Rheumatology)에서 각기 권고 가이드라인으로 삼고 있다.

\section{생물학적제제 일차치료 실패: 다음 선택은?}

항TNF 제제 치료에 불충분한 반응을 보이는 류마티스 관절염의 경우, 다른 종류의 항 TNF 제제를 사용할지, 항 $\mathrm{TNF}$ 제제가 아닌 다른 기전의 생물학적제제를 사용할지, 아 니면 표적합성 항류마티스제를 사용할지 고민스러운 부분 이다. ACR에서는 첫 항TNF 제제 실패 시 비항TNF 제제 계열 생물학적제제를 권고하고 있으나[8], EULAR는 어떤 계열을 사용할지 우선권을 제시하지 않았다. 하지만, 최근 2019 EULAR 권고안에서는 다른 작용기전을 가지는 약제 를 좀 더 우선 고려하도록 순서를 약간 조정하였다[15]. 최근 EXXELERATE 연구[38]가 발표되었는데, 초기 항TNF 제 제에 반응을 보이지 않을 경우 즉각 2차 항 TNF 제제로 교체 하면 임상적 효과가 호전된다고 하였다. 일반적으로 모든 생 물학적제제는 첫 항 TNF 제제 실패 후에 사용하는 것보다는 해당 생물학적제제를 일차 생물학적제제로 선택하였을 때 치료성적이 좋다. ACR과 EULAR 양 학회에서 2차 항 TNF 제제 실패 시에는 비 TNF 생물학적제제 혹은 표적합성 항류 마티스제로 교체하도록 권고하고 있다[8,15].

생물학적제제 간의 병합치료는 아바타셉트와 항 TNF 제 제[39], $\mathrm{IL}-1$ 수용체 억제제와 항TNF 제제[40], 리툭시맙 


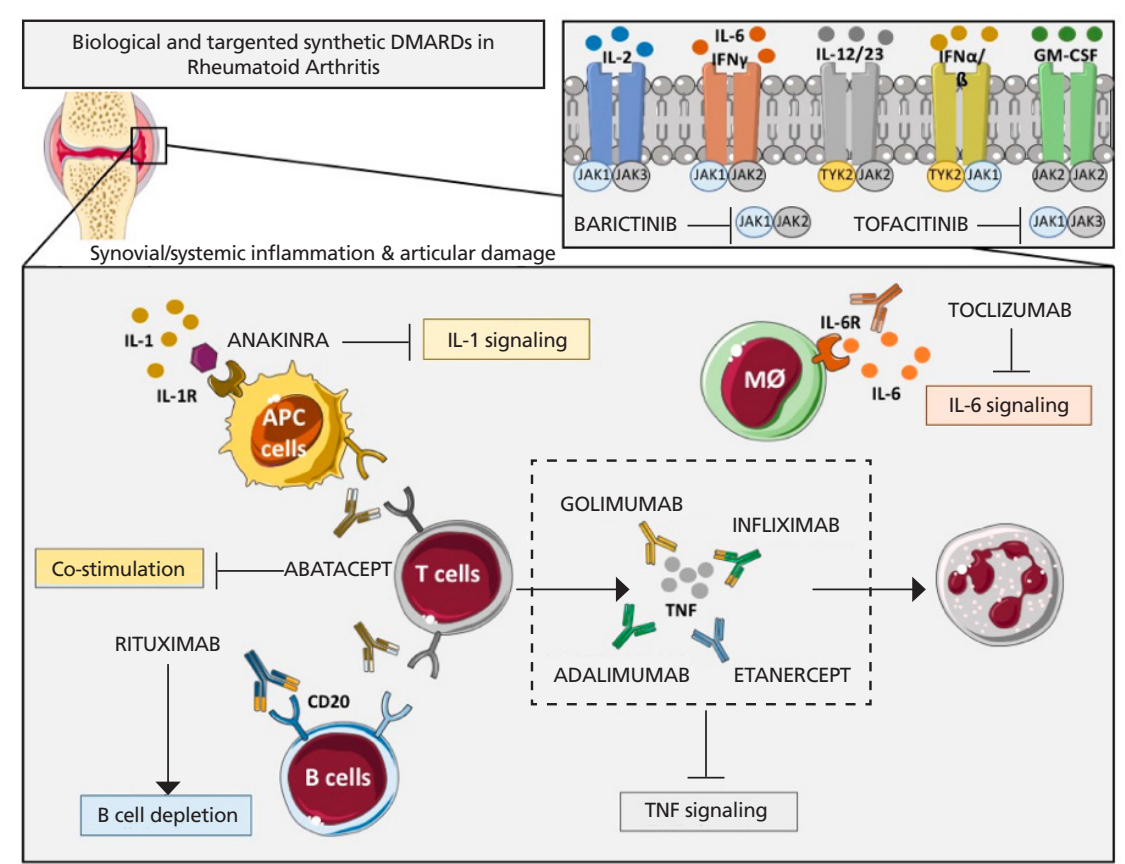

Figure 1. Overview of the main immunologic pathways targeted by the biological and targeted synthetic therapies in rheumatoid arthritis. Simplified description of cytokines and receptors that are targeted by available biologic disease-modifying antirheumatic drugs (DMARDs) such as tumor necrosis factor (TNF) inhibitors (adalimumab, golimumab, infliximab, and etanercept), interleukin (IL)-1R antagonist (anakinra), antibody against IL-6R (tocilizumab) and anti-CD20 (rituximab), and targeted synthetic DMARDs, such as Janus kinase (JAK) inhibitors (anti-JAKs): tofacitinib (JAK1-JAK3 inhibitor) and baricitinib (JAK1-JAK2 inhibitor). APC, antigen-presenting cells; $\mathrm{M} \varphi$, macrophage. Adapted from Lopez-Pedrera C et al. Int J Mol Sci 2020;21:9067, according to the Creative Commons license [32].

과 항TNF 제제를 병합하는[41] 연구가 있었는데, 심각한 감 염증 등의 이상반응의 빈도가 높고 추가적 이득은 적은 것 으로 밝혀졌다. 하지만, 앞으로는 감염의 위험을 높이지 않 고도 다양한 사이토카인 경로를 표적으로 치료하는 것이 가 능할 수도 있다. 예를 들면, 콜라겐 유도 관절염 마우스에 서 $\mathrm{IL}-1$ 베타와 $\mathrm{IL}-17 \mathrm{~A}$ 를 같이 표적으로 하는 항체치료 (FL-BsAB1/17)의 사용은 각각을 따로 치료하는 것에 비해 관절염 점수와 조직학적 병변을 개선시켰다. 또한 류마티스 관절염 환자 유래 활막에서 같은 약제인 $\mathrm{FL}-\mathrm{BsAB} 1 / 17$ 로 처리하였을 경우 $\mathrm{LL}-6$ 의 생성을 유의하게 감소시켰던 연구 도 있다[42].

\section{관해 도달 시 생물학적제제의 감량 혹은 중단}

EULAR 권고안에서, 관해에 도달한 류마티스관절염 환자
는 치료제 감량 및 중단을 시도할 수 있 는데, 순서는 글루코코르티코이드, 생물 학적제제, $\mathrm{csDMARDs}$ 의 순으로 감량한 다[15]. 류마티스관절염 환자에서 글루 코코르티코이드를 끓고도 관해에 도달 한 경우, 많은 수의 환자에서 생물학적 제제를 감량하거나, 중단하는 시도가 있 었다. 성공적으로 감량이나 중단을 하는 경우도 있으나 재발하는 경우 다시 처음 사용하였던 생물학적제제를 다시 시작 하면 조절이 잘되는 편이다[43].

감량의 경우 1 회 투여되는 약의 용량 을 줄이거나 투여간격을 늘이는 방법 이 있다. 약을 감량하면 경제적인 이득 이 있고, 부작용 발생이 적어진다. 지 속적으로 낮은 질병활성도를 보이는 류 마티스관절염 환자에서 반으로 감량한 $25 \mathrm{mg}$ 에타너셉트를 주1회로 사용하면 88주 경과 후 여전히 낮은 질병활성도 를 얻었다[44]. 아달리무맙의 경우도 질 병활성도를 모니터 하면서 감량하는 전략으로 $2 / 3$ 정도의 환자에서 재발없이 성공적인 감량이나 중단을 할 수 있었다 [45]. 따라서, 질병활성도 DAS28 점수가 관해를 유지할 때, 감량을 고려해야 하며, 어떤 환자군이 감량에 좀더 잘 반응 하고 약물 없는 관해에 도달할지 선택해야 한다. 어떤 예후 인자가 어떤 환자에서 좀더 약물 감량에 유리할지 무작위 대 조군 연구가 필요할 것이다[46].

\section{임신}

류마티스관절염은 여성에서 많고 가임기 여성에서 적지 않기 때문에, 류마티스내과 의사들은 생물학적제제를 선 택할 때 임신을 꼭 염두에 두어야 한다. 생물학적제제는 초기 개발당시 VATER 증후군 등 기형아 위험을 높일 것 으로 알려졌었으나, 데이터의 누적과 함께 최근 보고에는 
임신에 나쁜 영향이 적을 것으로 발표된다[47,48]. MTX, leflunomide는 임신중 절대 금기이며, 항TNF 제제는 비 교적 안전하여 임신 첫 삼분기에는 사용을 고려한다. 현재 는 임신기간 전반에 걸쳐 산모와 태아의 건강에 영향을 주 지 않고, 류마티스관절염 질병활성도를 최선으로 조절할 수 있도록 ACR에서 권고안을 발표하였다[49]. 특이점은 항TNF 제제 중에서 특히 서톨리주맙 페골이 태반통과가 적어 유럽의약청에서 최근 임신 내내 사용 가능하도록 승 인을 받았다[50].

\section{바이오시밀러}

유럽의약청과 $\mathrm{FDA}$ 에서 바이오시밀러에 대한 승인이 이 어지고 있어서, 각각의 원조 생물학적제와 비슷한 효과와 안 전성을 보이는 것으로 알려졌다. 인플릭시맙 바이오시밀러 (SB2, CTP13)들은 원조 인플릭시맙과 비교 시 ACR20 도 달률, 영상학적 진행 억제, 안전성과 면역원성이 비슷했다 [51,52]. 마찬가지로 에타너셉트와 그 바이오시밀러인 SB4 도 효과와 안전성이 견줄 만하다는 결과를 보였다[53]. 초기 의 ACR-EULAR 권고안에서는 바이오시밀러의 빠른 사용 에 대해 좀 더 지켜보자는 자세였으나, 최근의 권고안이나 유럽 여러 나라에서는 바이오시밀러와 원조 약품의 가격이 나 효과 안전성 등을 면밀히 고려하여 좀더 유리한 약물을 선택하려는 노력이 있다[15].

\section{암 발생}

생물학적제제 중에 가장 먼저 사용된 항 TNF 제제는 '종양 괴사인자 억제제' 기전의 특징으로, 종양괴사에 반대 영향을 끼쳐, 종양 혹은 암 발생이 더 흔할 것으로 생각되었다[54]. 하지만, 20 여 년간 관찰한 바에 의하면 $\mathrm{csDMARDs}$ 에 비해 생물학적제제 치료를 받는 환자들은 암 발생이 높지 않다. 다만 악성흑색종은 예외인데 비교위험도 1.5 정도로 생물학 적제제에서 높은 경향을 보였다[55].

\section{레지스트리 연구}

생물학적제제 간의 약물 생존률이나 부작용 발생 등을 확인하기 위하여 개별 연구기관 혹은 국가에서 등록사업 이 전 세계적으로 활발하게 이루어지고 있다[56]. 국내에 서도 KORONA (Korean Observational Study Network for Arthritis), KOBIO (Korean Biologics Registry of Patients with Systemic Rheumatic Disease) 등의 생물 학적제제 연구가 류마티스관절염, 루푸스, 강직척추염 등 을 대상으로 진행 중이며[57], 이런 연구를 토대로 외국의 사례를 확인해 볼 수도 있고, 국내의 환자 특성이나 동반질 환 별로 어떤 약제들이 가장 많이, 오래 사용되었는지 알아 볼 수도 있다.

\section{결론}

류마티스관절염의 치료는 생물학적제제의 도입과 함께 크게 발전하였다. 생물학적제제들은 약물마다 다양한 기전 을 가지고 있지만, 식품의약품안전처 승인을 받아 사용되 는 약제들 간의 효과는 모두 비슷하다. 따라서, 환자의 개 인적 특성에 가장 알맞은 치료제를 선택해야 하는데, 바이 오시밀러 약물까지 포함한다면 2021년 현재 선택의 폭이 10 가지 이상으로 매우 넓어 고민하게 된다. 왜냐하면 약물 의 작용기전에 따른 선택 이외에도 환자의 나이나 동반질 환, 류마티스인자 자가항체여부, 경제적 측면, 약물투여 경 로와 방법, 그리고 약제 특이적인 부작용 등을 모두 고려 하여 선택해야 하기 때문이다. 생물학적제제 사용 후에는 주기적인 모니터링으로 질병활성도가 목표(관해)에 도달하 는지 확인하며 약제를 조절한다. 치료목표에 도달하지 못 하였을 때에는 치료방법을 수정하고 장기간 관해에 도달한 환자에서는 약물의 감량을 시도해 볼 수 있다. 앞으로 류마 티스관절염 치료제 선택에 있어 생물학적제제들과 소분자 억제제에 대한 직접비교연구들과 레지스트리 관찰연구, 빅 데이터 분석 등이 더 많이 진행되어 약물선택에 도움이 되 었으면 한다. 


\section{찾아보기말: 류마티스관절염; 치료; 생물학적제제; 항류마티스약물}

\section{ORCID}

Sung-Jae Choi, https://orcid.org/0000-0002-0717-1203

\section{Conflict of Interest}

No potential conflict of interest relevant to this article was reported.

\section{References}

1.Won S, Cho SK, Kim D, Han M, Lee J, Jang EJ, Sung YK, Bae SC. Update on the prevalence and incidence of rheumatoid arthritis in Korea and an analysis of medical care and drug utilization. Rheumatol Int 2018;38:649-656.

2. Ministry of Food and Drug Safety. Regulation on approval and review of biological products [Internet]. Cheongju: Ministry of Food and Drug Safety; 2019 [cited 2021 Jan 8]. Available from: https://www.mfds.go.kr/docviewer/skin/doc. html?fn=20191129042200274.hwp\&rs=/docviewer/result/ data0010/14419/1/202101.

3.Agarwal SK. Biologic agents in rheumatoid arthritis: an update for managed care professionals. J Manag Care Pharm 2011;17(9 Suppl B):S14-S18.

4. Cho SK, Sung YK. Treatment strategy for patients with rheumatoid arthritis. J Korean Med Assoc 2020;63:422-430.

5.Chung ES, Packer M, Lo KH, Fasanmade AA, Willerson JT; Anti-TNF Therapy Against Congestive Heart Failure Investigators. Randomized, double-blind, placebo-controlled, pilot trial of infliximab, a chimeric monoclonal antibody to tumor necrosis factor-alpha, in patients with moderate-tosevere heart failure: results of the anti-TNF Therapy Against Congestive Heart Failure (ATTACH) trial. Circulation 2003;107:3133-3140.

6.Singh JA, Cameron C, Noorbaloochi S, Cullis T, Tucker M, Christensen R, Ghogomu ET, Coyle D, Clifford T, Tugwell P, Wells GA. Risk of serious infection in biological treatment of patients with rheumatoid arthritis: a systematic review and meta-analysis. Lancet 2015;386:258-265.

7.Lahiri M, Dixon WG. Risk of infection with biologic antirheumatic therapies in patients with rheumatoid arthritis. Best Pract Res Clin Rheumatol 2015;29:290-305.

8.Singh JA, Saag KG, Bridges SL Jr, Akl EA, Bannuru RR, Sullivan MC, Vaysbrot E, McNaughton C, Osani M, Shmerling RH, Curtis JR, Furst DE, Parks D, Kavanaugh A, O'Dell J, King C, Leong A, Matteson EL, Schousboe JT, Drevlow B, Ginsberg S, Grober J, St Clair EW, Tindall E, Miller AS, McAlindon T. 2015 American College of Rheumatology guideline for the treatment of rheumatoid arthritis. Arthritis Rheumatol 2016;68:1-26.
9.Burmester GR, Rubbert-Roth A, Cantagrel A, Hall S, Leszczynski P, Feldman D, Rangaraj MJ, Roane G, Ludivico C, Bao M, Rowell L, Davies C, Mysler EF. Efficacy and safety of subcutaneous tocilizumab versus intravenous tocilizumab in combination with traditional DMARDs in patients with RA at week 97 (SUMMACTA). Ann Rheum Dis 2016;75:68-74.

10.Strangfeld A, Richter A, Siegmund B, Herzer P, Rockwitz K, Demary W, Aringer M, Meißner Y, Zink A, Listing J. Risk for lower intestinal perforations in patients with rheumatoid arthritis treated with tocilizumab in comparison to treatment with other biologic or conventional synthetic DMARDs. Ann Rheum Dis 2017;76:504-510.

11.Aletaha D, Bingham CO 3rd, Tanaka Y, Agarwal P, Kurrasch R, Tak PP, Popik S. Efficacy and safety of sirukumab in patients with active rheumatoid arthritis refractory to antiTNF therapy (SIRROUND-T): a randomised, double-blind, placebo-controlled, parallel-group, multinational, phase 3 study. Lancet 2017;389:1206-1217.

12.Takeuchi T, Tanaka Y, Yamanaka H, Amano K, Nagamine R, Park W, Shiozawa K, Tsukano M, Wei JC, Shao J, Togo $\mathrm{O}$, Mashimo H. Efficacy and safety of olokizumab in Asian patients with moderate-to-severe rheumatoid arthritis, previously exposed to anti-TNF therapy: results from a randomized phase II trial. Mod Rheumatol 2016;26:15-23.

13.Jones G, Sebba A, Gu J, Lowenstein MB, Calvo A, GomezReino JJ, Siri DA, Tomsic M, Alecock E, Woodworth T, Genovese MC. Comparison of tocilizumab monotherapy versus methotrexate monotherapy in patients with moderate to severe rheumatoid arthritis: the AMBITION study. Ann Rheum Dis 2010;69:88-96.

14.Gabay C, Emery P, van Vollenhoven R, Dikranian A, Alten R, Pavelka K, Klearman M, Musselman D, Agarwal S, Green J, Kavanaugh A; ADACTA Study Investigators. Tocilizumab monotherapy versus adalimumab monotherapy for treatment of rheumatoid arthritis (ADACTA): a randomised, doubleblind, controlled phase 4 trial. Lancet 2013;381:1541-1550.

15.Smolen JS, Landewe RBM, Bijlsma JWJ, Burmester GR, Dougados M, Kerschbaumer A, McInnes IB, Sepriano A, van Vollenhoven RF, de Wit M, Aletaha D, Aringer M, Askling J, Balsa A, Boers M, den Broeder AA, Buch MH, Buttgereit F, Caporali R, Cardiel MH, De Cock D, Codreanu C, Cutolo M, Edwards CJ, van Eijk-Hustings Y, Emery P, Finckh A, Gossec L, Gottenberg JE, Hetland ML, Huizinga TWJ, Koloumas M, Li Z, Mariette X, Müller-Ladner U, Mysler EF, da Silva JAP, Poór G, Pope JE, Rubbert-Roth A, Ruyssen-Witrand A, Saag KG, Strangfeld A, Takeuchi T, Voshaar M, Westhovens R, van der Heijde D. EULAR recommendations for the management of rheumatoid arthritis with synthetic and biological diseasemodifying antirheumatic drugs: 2019 update. Ann Rheum Dis 2020;79:685-699.

16.Genovese MC, Becker JC, Schiff M, Luggen M, Sherrer Y, Kremer J, Birbara C, Box J, Natarajan K, Nuamah I, Li T, Aranda R, Hagerty DT, Dougados M. Abatacept for rheumatoid arthritis refractory to tumor necrosis factor alpha inhibition. N Engl J Med 2005;353:1114-1123.

17. Park KS. Biopharmacetutical product. In: Korean College 
of Rheumatology. KCR textbook of rheumatology. 2nd ed. Seoul: Panmun Education; 2018. p. 135-140.

18.Bonelli M, Ferner E, Goschl L, Blüml S, Hladik A, Karonitsch T, Kiener HP, Byrne R, Niederreiter B, Steiner CW, Rath E, Bergmann M, Smolen JS, Scheinecker C. Abatacept (CTLA4IG) treatment reduces the migratory capacity of monocytes in patients with rheumatoid arthritis. Arthritis Rheum 2013;65:599-607.

19. Cohen SB, Emery P, Greenwald MW, Dougados M, Furie RA, Genovese MC, Keystone EC, Loveless JE, Burmester GR, Cravets MW, Hessey EW, Shaw T, Totoritis MC; REFLEX Trial Group. Rituximab for rheumatoid arthritis refractory to anti-tumor necrosis factor therapy: Results of a multicenter, randomized, double-blind, placebo-controlled, phase III trial evaluating primary efficacy and safety at twenty-four weeks. Arthritis Rheum 2006;54:2793-2806.

20.Chen MH, Chen MH, Liu CY, Tsai CY, Huang DF, Lin HY, Lee MH, Huang YH. Hepatitis B virus reactivation in rheumatoid arthritis patients undergoing biologics treatment. J Infect Dis 2017;215:566-573.

21.Molloy ES, Calabrese CM, Calabrese LH. The Risk of Progressive multifocal leukoencephalopathy in the biologic era: prevention and management. Rheum Dis Clin North Am 2017;43:95-109.

22.Abushouk AI, Ahmed H, Ismail A, Elmaraezy A, Badr AS, Gadelkarim M, Elnenny M. Safety and efficacy of ocrelizumab in rheumatoid arthritis patients with an inadequate response to methotrexate or tumor necrosis factor inhibitors: a systematic review and meta-analysis. Rheumatol Int 2017;37:1053-1064.

23.Taylor PC, Quattrocchi E, Mallett S, Kurrasch R, Petersen J, Chang DJ. Ofatumumab, a fully human anti-CD20 monoclonal antibody, in biological-naive, rheumatoid arthritis patients with an inadequate response to methotrexate: a randomised, double-blind, placebo-controlled clinical trial. Ann Rheum Dis 2011;70:2119-2125.

24.Hamilton JA. GM-CSF as a target in inflammatory/ autoimmune disease: current evidence and future therapeutic potential. Expert Rev Clin Immunol 2015;11:457-465.

25.Behrens F, Tak PP, Ostergaard M, Stoilov R, Wiland P, Huizinga TW, Berenfus VY, Vladeva S, Rech J, Rubbert-Roth A, Korkosz M, Rekalov D, Zupanets IA, Ejbjerg BJ, Geiseler J, Fresenius J, Korolkiewicz RP, Schottelius AJ, Burkhardt H. MOR103, a human monoclonal antibody to granulocytemacrophage colony-stimulating factor, in the treatment of patients with moderate rheumatoid arthritis: results of a phase Ib/IIa randomised, double-blind, placebo-controlled, doseescalation trial. Ann Rheum Dis 2015;74:1058-1064.

26.Scott IC, Ibrahim F, Simpson G, Kowalczyk A, WhiteAlao B, Hassell A, Plant M, Richards S, Walker D, Scott DL. A randomised trial evaluating anakinra in early active rheumatoid arthritis. Clin Exp Rheumatol 2016;34:88-93.

27.Smolen JS, Agarwal SK, Ilivanova E, Xu XL, Miao Y, Zhuang Y, Nnane I, Radziszewski W, Greenspan A, Beutler A, Baker D. A randomised phase II study evaluating the efficacy and safety of subcutaneously administered ustekinumab and guselkumab in patients with active rheumatoid arthritis despite treatment with methotrexate. Ann Rheum Dis 2017;76:831-839.

28. Chabaud M, Durand JM, Buchs N, Fossiez F, Page G, Frappart L, Miossec P. Human interleukin-17: a T cell-derived proinflammatory cytokine produced by the rheumatoid synovium. Arthritis Rheum 1999;42:963-970.

29.Genovese MC, Durez P, Richards HB, Supronik J, Dokoupilova E, Mazurov V, Aelion JA, Lee SH, Codding CE, Kellner H, Ikawa T, Hugot S, Mpofu S. Efficacy and safety of secukinumab in patients with rheumatoid arthritis: a phase II, dose-finding, double-blind, randomised, placebo controlled study. Ann Rheum Dis 2013;72:863-869.

30.Martin DA, Churchill M, Flores-Suarez L, Cardiel MH, Wallace D, Martin R, Phillips K, Kaine JL, Dong H, Salinger D, Stevens E, Russell CB, Chung JB. A phase Ib multiple ascending dose study evaluating safety, pharmacokinetics, and early clinical response of brodalumab, a human anti-IL17R antibody, in methotrexate-resistant rheumatoid arthritis. Arthritis Res Ther 2013;15:R164.

31.Genovese MC, Greenwald M, Cho CS, Berman A, Jin L, Cameron GS, Benichou O, Xie L, Braun D, Berclaz PY, Banerjee S. A phase II randomized study of subcutaneous ixekizumab, an anti-interleukin-17 monoclonal antibody, in rheumatoid arthritis patients who were naive to biologic agents or had an inadequate response to tumor necrosis factor inhibitors. Arthritis Rheumatol 2014;66:1693-1704.

32.Lopez-Pedrera C, Barbarroja N, Patino-Trives AM, LuqueTevar M, Collantes-Estevez E, Escudero-Contreras A, PerezSanchez C. Effects of biological therapies on molecular features of rheumatoid arthritis. Int J Mol Sci 2020;21:9067.

33.Braun J, Kastner P, Flaxenberg P, Wahrisch J, Hanke P, Demary W, von Hinuber U, Rockwitz K, Heitz W, Pichlmeier U, Guimbal-Schmolck C, Brandt A; MC-MTX.6/RH Study Group. Comparison of the clinical efficacy and safety of subcutaneous versus oral administration of methotrexate in patients with active rheumatoid arthritis: results of a sixmonth, multicenter, randomized, double-blind, controlled, phase IV trial. Arthritis Rheum 2008;58:73-81.

34.Nikiphorou E, Negoescu A, Fitzpatrick JD, Goudie CT, Badcock A, Ostor AJ, Malaviya AP. Indispensable or intolerable? Methotrexate in patients with rheumatoid and psoriatic arthritis: a retrospective review of discontinuation rates from a large UK cohort. Clin Rheumatol 2014;33:609614.

35.Soliman MM, Ashcroft DM, Watson KD, Lunt M, Symmons DP, Hyrich KL; British Society for Rheumatology Biologics Register. Impact of concomitant use of DMARDs on the persistence with anti-TNF therapies in patients with rheumatoid arthritis: results from the British Society for Rheumatology Biologics Register. Ann Rheum Dis 2011;70:583-589.

36.Park SH, Lee MY, Lee EK. Cost-minimization analysis of biologic disease-modifying antirheumatic drugs administered by subcutaneous injections in patients with rheumatoid arthritis. Korean J Clin Pharm 2016;26:59-69. 
37.Smolen JS, Breedveld FC, Burmester GR, Bykerk V, Dougados M, Emery P, Kvien TK, Navarro-Compan MV, Oliver S, Schoels M, Scholte-Voshaar M, Stamm T, Stoffer M, Takeuchi T, Aletaha D, Andreu JL, Aringer M, Bergman M, Betteridge N, Bijlsma H, Burkhardt H, Cardiel M, Combe B, Durez P, Fonseca JE, Gibofsky A, Gomez-Reino JJ, Graninger W, Hannonen P, Haraoui B, Kouloumas M, Landewe R, MartinMola E, Nash P, Ostergaard M, Ostor A, Richards P, SokkaIsler T, Thorne C, Tzioufas AG, van Vollenhoven R, de Wit M, van der Heijde D. Treating rheumatoid arthritis to target: 2014 update of the recommendations of an international task force. Ann Rheum Dis 2016;75:3-15.

38.Smolen JS, Burmester GR, Combe B, Curtis JR, Hall S, Haraoui B, van Vollenhoven R, Cioffi C, Ecoffet C, Gervitz L, Ionescu L, Peterson L, Fleischmann R. Head-to-head comparison of certolizumab pegol versus adalimumab in rheumatoid arthritis: 2-year efficacy and safety results from the randomised EXXELERATE study. Lancet 2016;388:27632774.

39. Weinblatt M, Combe B, Covucci A, Aranda R, Becker JC, Keystone E. Safety of the selective costimulation modulator abatacept in rheumatoid arthritis patients receiving background biologic and nonbiologic disease-modifying antirheumatic drugs: a one-year randomized, placebocontrolled study. Arthritis Rheum 2006;54:2807-2816.

40.Genovese MC, Cohen S, Moreland L, Lium D, Robbins S, Newmark R, Bekker P; 20000223 Study Group. Combination therapy with etanercept and anakinra in the treatment of patients with rheumatoid arthritis who have been treated unsuccessfully with methotrexate. Arthritis Rheum 2004;50:1412-1419.

41.Greenwald MW, Shergy WJ, Kaine JL, Sweetser MT, Gilder $\mathrm{K}$, Linnik MD. Evaluation of the safety of rituximab in combination with a tumor necrosis factor inhibitor and methotrexate in patients with active rheumatoid arthritis: results from a randomized controlled trial. Arthritis Rheum 2011;63:622-632.

42.Wang Y, Wu Q, Liu Z, Guo X, Zhou L, Wang Y, Song L, Wang N, Zheng Q, Wang W, Ren G, Li D. A recombinant IgG-like bispecific antibody acting as interleukin- $1 \beta$ and interleukin$17 \mathrm{~A}$ inhibitor exhibits a promising efficacy for rheumatoid arthritis. Biomed Pharmacother 2017;89:426-437.

43. Haschka J, Englbrecht M, Hueber AJ, Manger B, Kleyer A, Reiser M, Finzel S, Tony HP, Kleinert S, Feuchtenberger M, Fleck M, Manger K, Ochs W, Schmitt-Haendle M, Wendler J, Schuch F, Ronneberger M, Lorenz HM, Nuesslein H, Alten R, Demary W, Henes J, Schett G, Rech J. Relapse rates in patients with rheumatoid arthritis in stable remission tapering or stopping antirheumatic therapy: interim results from the prospective randomised controlled RETRO study. Ann Rheum Dis 2016;75:45-51.

44.Smolen JS, Nash P, Durez P, Hall S, Ilivanova E, IrazoquePalazuelos F, Miranda P, Park MC, Pavelka K, Pedersen R, Szumski A, Hammond C, Koenig AS, Vlahos B. Maintenance, reduction, or withdrawal of etanercept after treatment with etanercept and methotrexate in patients with moderate rheumatoid arthritis (PRESERVE): a randomised controlled trial. Lancet 2013;381:918-929.

45.van Herwaarden N, van der Maas A, Minten MJ, van den Hoogen FH, Kievit W, van Vollenhoven RF, Bijlsma JW, van den Bemt BJ, den Broeder AA. Disease activity guided dose reduction and withdrawal of adalimumab or etanercept compared with usual care in rheumatoid arthritis: open label, randomised controlled, non-inferiority trial. BMJ 2015;350:h1389.

46.Nam JL, Takase-Minegishi K, Ramiro S, Chatzidionysiou K, Smolen JS, van der Heijde D, Bijlsma JW, Burmester GR, Dougados M, Scholte-Voshaar M, van Vollenhoven R, Landewe R. Efficacy of biological disease-modifying antirheumatic drugs: a systematic literature review informing the 2016 update of the EULAR recommendations for the management of rheumatoid arthritis. Ann Rheum Dis 2017;76:1113-1136.

47.Carter JD, Valeriano J, Vasey FB. Tumor necrosis factor-alpha inhibition and VATER association: a causal relationship. J Rheumatol 2006;33:1014-1017.

48.Diav-Citrin O, Otcheretianski-Volodarsky A, Shechtman S, Ornoy A. Pregnancy outcome following gestational exposure to TNF-alpha-inhibitors: a prospective, comparative, observational study. Reprod Toxicol 2014;43:78-84.

49.Sammaritano LR, Bermas BL, Chakravarty EE, Chambers C, Clowse MEB, Lockshin MD, Marder W, Guyatt G, Branch DW, Buyon J, Christopher-Stine L, Crow-Hercher R, Cush J, Druzin M, Kavanaugh A, Laskin CA, Plante L, Salmon J, Simard J, Somers EC, Steen V, Tedeschi SK, Vinet E, White CW, Yazdany J, Barbhaiya M, Bettendorf B, Eudy A, Jayatilleke A, Shah AA, Sullivan N, Tarter LL, Birru Talabi M, Turgunbaev M, Turner A, D'Anci KE. 2020 American College of Rheumatology Guideline for the Management of Reproductive Health in Rheumatic and Musculoskeletal Diseases. Arthritis Rheumatol 2020;72:529-556.

50. Mariette X, Forger F, Abraham B, Flynn AD, Molto A, Flipo RM, van Tubergen A, Shaughnessy L, Simpson J, Teil M, Helmer E, Wang M, Chakravarty EF. Lack of placental transfer of certolizumab pegol during pregnancy: results from CRIB, a prospective, postmarketing, pharmacokinetic study. Ann Rheum Dis 2018;77:228-233.

51.Choe JY, Prodanovic N, Niebrzydowski J, Staykov I, Dokoupilova E, Baranauskaite A, Yatsyshyn R, Mekic M, Porawska W, Ciferska H, Jedrychowicz-Rosiak K, Zielinska A, Choi J, Rho YH, Smolen JS. A randomised, double-blind, phase III study comparing SB2, an infliximab biosimilar, to the infliximab reference product Remicade in patients with moderate to severe rheumatoid arthritis despite methotrexate therapy. Ann Rheum Dis 2017;76:58-64.

52.Yoo DH, Racewicz A, Brzezicki J, Yatsyshyn R, Arteaga ET, Baranauskaite A, Abud-Mendoza C, Navarra S, Kadinov V, Sariego IG, Hong SS, Lee SY, Park W. A phase III randomized study to evaluate the efficacy and safety of CT-P13 compared with reference infliximab in patients with active rheumatoid arthritis: 54-week results from the PLANETRA study. Arthritis Res Ther 2016;18:82.

53.Emery P, Vencovsky J, Sylwestrzak A, Leszczynski P, Porawska 
W, Baranauskaite A, Tseluyko V, Zhdan VM, Stasiuk B, Milasiene R, Barrera Rodriguez AA, Cheong SY, Ghil J. A phase III randomised, double-blind, parallel-group study comparing SB4 with etanercept reference product in patients with active rheumatoid arthritis despite methotrexate therapy. Ann Rheum Dis 2017;76:51-57.

54.Askling J, Bongartz T. Malignancy and biologic therapy in rheumatoid arthritis. Curr Opin Rheumatol 2008;20:334-339.

55.Ramiro S, Sepriano A, Chatzidionysiou K, Nam JL, Smolen JS, van der Heijde D, Dougados M, van Vollenhoven R, Bijlsma JW, Burmester GR, Scholte-Voshaar M, Falzon L, Landewé RBM. Safety of synthetic and biological DMARDs: a systematic literature review informing the 2016 update of the EULAR recommendations for management of rheumatoid arthritis. Ann Rheum Dis 2017;76:1101-1136.

56.Lee JE, Shim DY, Yoon D, Noh Y, Shin JY. Current status and examples of patient registries in the US, Europe, and Japan and proposal of planning patient registry in Korea. Yakhak Hoeji 2020;64:358-368.

57.Shin K, Choi SJ, Kwak SK, Park YB, Sung YK, Choi CB, Jeon CH, Lee J, Nam EJ, Kim SK, Kim HA, Lee CH, Lee SS, Yoo DH. AB1066 Korean Biologics Registry of patients with systemic rheumatic disease (KOBIO): a nationwide registry to assess adverse events associated with biologic treatment in Korea [abstract]. Ann Rheum Dis 2014;73(Suppl 2):11531154.

\section{Peer Reviewers' Commentary}

류마티스관절염은 관절염과 함께 전신을 침범하여 환자의 생명 을 위협하고, 삶의 질을 현저히 떨어뜨리며, 막대한 경제적 사회 적 부담을 주는 위험한 전신질환이다. 류마티스관절염은 불치병 으로 알려져 왔으나, 최근에 다양한 종류의 생물학적제제가 치 료에 도입되어 혁명적인 효과를 보이고 있다. 이 논문에서는 류 마티스관절염 치료를 위한 생물학적제제의 종류와 특성, 작용기 전, 효과와 부작용, 환자의 상태에 따른 약물의 맞춤형 선택 사 항 등을 최신 지식을 정리하여 자세히 소개하고 있다. 또한 가장 최근에 개발된 생물학적제제(바이오시밀러 포함)까지 소개하고 있어, 생물학적제제를 이용한 류마티스관절염 치료에 있어서 아 주 유용한 지침을 제공해 줄 것으로 판단된다.

[정리: 편집위원회] 